\title{
PENGARUH PEMBERIAN SEDIAAN MIKROEMULSI EKSTRAK BAWANG DAYAK (Eleutherine bulbosa (Mill.) Urb) DAN MIKROEMULSI DAUN BUNGUR (Lagerstronemia speciosa L. Pers.) TERHADAP PENURUNAN KADAR KOLESTEROL TOTAL PADA TIKUS YANG DIINDUKSI PAKAN TINGGI KOLESTEROL
}

\author{
Mensie Martha Lovianie ${ }^{1}$ Dewi Shoimah ${ }^{2}$ Ahmad Yanor $^{3}$ \\ ${ }^{123}$ STIKes Borneo Cendekia Medika Pangkalan Bun \\ ${ }^{1}$ email mensiemartha34@gmail.com, ${ }^{2}$ email : Dewishoimah9593@gmail.com,
}

\begin{abstract}
ABSTRAK
Kadar kolesterol dalam darah yang tinggi dapat meningkatkan resiko terjadinya penyakit jantung koroner. Bawang dayak (Eleutherine bulbosa (Mill.) Urb) merupakan tanaman khas Kalimantan Tengah yang dipercaya masyarakat dayak dapat menurunkan kadar kolesterol. Senyawa dalam tanaman bawang dayak yang dapat menurunkan kadar kolesterol adalah flavonoid, saponin, dan tanin. Salah satu tumbuhan yang mengandung senyawa obat yaitu tumbuhan bungur (Lagerstronemia speciosa L. Pers.). Hasil analisis fitokimia menunjukkan bahwa ekstrak daun bungur mengandung flavonoid sebanyak 13,65\%. Flavonoid telah terbukti dapat memperbaiki profil lipid darah dan memiliki efek vasoprotektif (Shipp dan AbdelAal, 2010).

Penelitian menggunakan 15 ekor tikus putih jantan galur wistar yang diinduksi pakan tinggi kolesterol. Tikus dibagi menjadi 3 kelompok, yaitu kelompok kontrol negatif mikroemulsi placebo, kontrol positif mikroemulsi simvastatin $0,18 \mathrm{mg} / 200 \mathrm{~g} \mathrm{BB}$ tikus, serta kelompok perlakuan mikroemulsi bawang dayak dan mikroemulsi daun bungur $180 \mathrm{mg} / 200 \mathrm{~g}$ BB tikus yang diberikan secara peroral. Pengukuran kadar kolesterol total dilakukan pada hari ke-0 (kadar awal), hari ke-21 (kadar setelah induksi) dan hari ke-28 (kadar setelah perlakuan). Persen penurunan kadar kolesterol total dalam darah dianalisis secara statistika dengan taraf kepercayaan 95\%.

Hasil uji statistika menyatakan ada perbedaan antara kelompok kontrol negatif dengan dengan kelompok perlakuan mikroemulsi bawang dayak memiliki nilai signifikansi 0,000 sedangkan pada kelompok kontrol positif dan kelompok mikroemulsi bawang dayak tidak ada perbedaan yang signifikan memiliki nilai signifikansi 0,782. Mikroemulsi bawang dayak (Eleutherine bulbosa (Mill.) Urb) dapat menurunkan kadar kolesterol total tikus yang diinduksi pakan tinggi kolesterol dan memiliki kemampuan yang sebanding dengan mikroemulsi simvastatin.
\end{abstract}

Kata kunci : Mikroemulsi, bawang dayak (Eleutherine bulbosa (Mill.) Urb), daun bungur (Lagerstronemia speciosa L. Pers.), kolesterol total, simvastatin. 
THE INFLUENCE OF THE PROVISION OF PREPARATION MIKROEMULSI EXTRACT BAWANG DAYAK ( ELEUTHERINE BULBOSA (MILL . )URB) AND MICROEMULTION BUNGUR LEAF (LAGERSTRONEMIA SPECIOSA L. PERS.) TO A DECREASE IN CHOLESTEROL LEVELS TOTAL IN MICE INDUCED FEED HIGH CHOLESTEROL

\begin{abstract}
High blood cholesterol can increase the risk of coronary heart disease. Dayak onion (Eleutherine bulbosa (Mill.) Urb) is a typical plant of Central Kalimantan which is believed by the Dayak community to reduce cholesterol levels. Compounds in Dayak onion plants that can reduce cholesterol levels are flavonoids, saponins, and tannins. One of the plants that contain medicinal compounds is the bungur plant (Lagerstronemia speciosa L. Pers.). The results of phytochemical analysis showed that the extract of bungur leaf contained flavonoids as much as $13.65 \%$. Flavonoids have been shown to improve blood lipid profiles and have a vasoprotective effect (Shipp and Abdel-Aal, 2010). The study used 15 white male wistar rats induced by high cholesterol feed. The rats were divided into 3 groups, namely the placebo microemulsion negative control group, simvastatin positive microemulsion control $0.18 \mathrm{mg} / 200 \mathrm{~g} \mathrm{BW}$ rats, and the microemulsion treatment group on dayak onions and microemulsion of $180 \mathrm{mg} / 200 \mathrm{~g} \mathrm{BW}$ leaf microemulsion rats administered orally. Measurement of total cholesterol levels was carried out on day 0 (initial level), day 21 (levels after induction) and day 28 (levels after treatment). Percent decrease in total cholesterol in the blood analyzed statistically with a confidence level of $95 \%$. Statistical test results stated that there were differences between the negative control group and the dayak onion microemulsion treatment group having a significance value of 0,000 while in the positive control group and dayak onion microemulsion group there were no significant differences having a significance value of 0.782 . Dayak onion (Eleutherine bulbosa (Mill.) Urb) microemulsion can reduce the total cholesterol level of rats induced by high cholesterol feed and has comparable ability to simvastatin microemulsion.
\end{abstract}

Keywords: Microemulsion, Dayak onion (Eleutherine bulbosa (Mill.) Urb), bungur leaf (Lagerstronemia speciosa L. Pers.), total cholesterol, simvastatin.

\section{PENDAHULUAN}

Masyarakat Indonesia cenderung suka mengikuti budaya asing sehingga terjadi perubahan gaya hidup pada masyarakat, salah satunya adalah tren makanan cepat saji. Makanan tersebut memiliki kandungan kolesterol tinggi 
serta nutrisi yang sedikit. Makanan tersebut jika dikonsumsi terus menerus akan membahayakan kesehatan serta dapat meningkatkan resiko terkena penyakit degeneratif, sehingga fungsi dan struktur organ hingga jaringan dalam tubuh dapat menurun dari waktu ke waktu. Beberapa penyakit degeneratif meliputi penyakit kardiovaskular dan penyakit jantung koroner ${ }^{1}$.

Penyakit kardiovaskular dan penyakit jantung koroner salah satu penyebabnya adalah kadar kolesterol tinggi. Kolesterol adalah molekul sejenis lemak dalam aliran darah, berwarna kekuningan, diproduksi di hati dan sangat diperlukan oleh tubuh. Kolesterol sebenarnya tersusun atas berbagai macam zat, termasuk di dalamnya terdapat Trigliserida, LDL, dan HDL. Kelebihan kadar kolesterol dalam darah berpotensi dapat menyumbat pembuluh darah koroner dan menimbulkan iskemia hingga berujung pada kematian ${ }^{2}$.

Umbi bawang dayak mengandung flavonoid yang tinggi dan dapat berkhasiat sebagai antioksidan. Flavonoid yang bekerja secara maksimal sebagai antioksidan, flavonoid diketahui dapat menurunkan kadar kolesterol total dengan mekanisme menghambat aktivitas enzim HMG CoA reduktase yang berperan penting dalam biosintesis kolesterol $^{3}$. Flavonoid juga dapat bertindak sebagai kofaktor enzim kolesterol esterase dan inhibitor absorbsi kolesterol makanan dengan menghambat pembentukan misel sehingga penyerapan kolesterol terhambat.

Salah satu tumbuhan yang juga sering digunakan sebagai obat di masyarakat yaitu tumbuhan bungur (Lagerstronemia speciosa L. Pers.). Hasil analisis fitokimia menunjukkan bahwa ekstrak daun bungur mengandung flavonoid sebanyak $13,65 \%$. Flavonoid telah terbukti dapat memperbaiki profil lipid darah dan memiliki efek vasoprotektif.

Penelitian ini bertujuan untuk mengetahui pengaruh pemberian mikroemulsi bawang dayak dan mikroemulsi daun bungur dalam menurunkan kadar kolesterol.

\section{METODE PENELITIAN}

Penelitian ini merupakan penelitian eksperimen laboratorium

\section{Alat dan bahan}

Alat. Sonde oral, kandang tikus beserta tempat makan dan minum, timbangan analitik (Centaurus Scale), timbangan analog, sentrifuse (Wina Instrument), tabung sentrifuse, alat pengambil darah (mikrohematokrit non heparin), rak tabung, beaker glass (Herma), gelas ukur, corong, labu takar, erlenmeyer, tabung reaksi, hotplate magnetic stirer (Wina Instrument), ayakan, pisau, blender, spektrofotometer UV-Visible (Photometer 5010 $\mathrm{V5}_{+}$), kertas saring, $\mathrm{pH}$ indikator universal, batang pengaduk, ultra turrax, partical size analyzer (Horiba SZ-100), morter dan 
stamper.

Bahan Uji: Umbi bawang dayak (Eleutherine bulbosa (Mill.) Urb) dan daun bungur. Bahan penginduksi: Bahan penginduksi yang digunakan adalah pakan standar, kuning telur puyuh dan lemak sapi. Bahan pembanding: Simvastatin (Kimia Farma). Hewan uji: Hewan uji yang digunakan adalah tikus putih jantan galur wistar berumur 4-5 bulan dengan berat badan 150-250 gram. Bahan kimia dan habis pakai : Etanol 70\% (Infarmind Farmasi Industri), etanol 96\% (Teknis), $\mathrm{H}_{2} \mathrm{SO}_{4}$ (Merck), VCO (Raja Kelapa), span 80 (Teknis), tween 80 (Teknis), $\mathrm{Na}_{2} \mathrm{HPO}_{4}$ (Teknis), $\mathrm{KH}_{2} \mathrm{PO}_{4}$ (Teknis), $\mathrm{NaCl}$ (Teknis), gliserin (Teknis), natrium benzoat (Teknis), asam sitrat (Teknis), asam asetat anhidrat (Teknis), kloroform (Teknis), pereaksi dragendorf (Teknis), serbuk Mg (Teknis), $\mathrm{HCl}$ (Merck), $\mathrm{FeCl}_{3}$ (Teknis), enzyme reagent R1 kolesterol total (Pro Analisis), dan aquadestilata (Teknis).

\section{Prosedur kerja}

Pembuatan ekstrak etanol. Umbi bawang dayak dan daun bungur yang telah diserbukkan ditimbang untuk kemudian dimasukkan ke dalam toples maserasi dan ditambahkan etanol 70 . Maserasi dilakukan dengan cara : 10 bagian simplisia dengan derajat halus yang cocok dimasukkan dalam bejana, kemudian dituangi dengan 75 bagian cairan penyari, ditutup, dibiarkan selama 5 hari, terlindung dari cahaya sambil sesekali digojog. Setelah 5 hari, sari diserkai, ampas diserap, sehingga diperoleh seluruh sari sebanyak 100 bagian $^{4}$.

Perlakuan Hewan Uji. Sebelum diberi perlakuan, tikus (20 ekor) diadaptasikan dahulu dengan keadaan laboratorium selama 3 hari dengan memberikan pakan standar. Setelah diadaptasi pada hari selanjutnya $(\mathrm{H} 0)$ maka dilakukan analisis kadar kolesterol total terhadap semua hewan uji. Setelah diambil sampel darah dan diketahui kadar kolesterol totalnya maka pada hari itu juga tikus diberi pakan tinggi kolesterol agar kadar kolesterolnya meningkat dilakukan selama 20 hari sebanyak 20 gram per tikus/hari sisa pakan ditimbang setiap hari, sebelum diganti dengan pakan yang baru serta diberi air minum sebanyak ad libitum. Kandang dibersihkan setiap 2 hari sekali. Pada hari ke 21 (H21) tikus diukur kadar kolesterol totalnya kembali untuk mengetahui seberapa besar peningkatan kadar kolesterol totalnya. Pada hari ke 21 - 28 tikus yang terdiri dari 3 kelompok diberi perlakuan sebagai berikut.:

$\begin{array}{ll}\begin{array}{l}\text { Kelompok I dan II } \\ \text { (kontrol negatif) }\end{array} & \begin{array}{l}\text { Mikroemulsi } \\ \text { Plasebo }\end{array} \\ \text { Kelompok III dan } & \text { Mikroemulsi } \\ \text { IV (kontrol } & \begin{array}{l}\text { Simvastatin 0,18 } \\ \text { mg/200 gBB tikus } \\ \text { positif) }\end{array} \\ \text { Mikroemulsi } \\ \text { Kelompok V } & \begin{array}{l}\text { Bawang Dayak } \\ \text { Mikroemulsi }\end{array} \\ \text { Kelompok VI } & \text { Daun Bungur }\end{array}$

Pada hari ke 28 (H28) semua hewan percobaan diambil darahnya kembali 
untuk mengetahui seberapa besar penurunannya. Darah diambil melalui vena mata selanjutnya darah didiamkan selama 15 menit, kemudian disentrifuge dengan kecepatan 3000 rpm selama 15 menit, dan setelah terpisah maka serum diambil untuk dilakukan penetapan kadar kolesterol totalnya.

\section{Pengukuran Kadar Kolesterol Total}

Pengukuran kadar kolesterol darah dilakukan dengan "CHODPAP":

enzymatice photometric test, yang diawali dengan mengambil darah tikus dari sinus orbitalis kemudian disentrifuge selama kurang lebih 15 menit. Setelah mendapatkan serum darah selanjutnya diambil kira-kira 10 mikro dimasukkan dalam tabung ependrof dan ditambah 10 mikro larutan standart, kemudian disiapkan pula larutan blangko berupa aquadest 10 mikro ke dalam masing-masing tabung sampel dan blangko dimasukkan $1000 \mathrm{ml}$ reagent, lalu dicampur. Langkah selanjutnya diinkubasi selama 20 menit pada suhu 37 derajat celcius, kemudian diukur. Setelah diketahui absorbansinya kadar kolesterol serum darah dihitung dengan rumus sebagai berikut:

Kolesterol $(\mathrm{mg} / \mathrm{dL})=\Delta$ A sample $\mathrm{x}$ konsentrasi standart/cal (mg/dL)

$\Delta \mathrm{A} \mathrm{std} / \mathrm{cal}$

Bila dikonversi maka:

Kolesterol (mg/dl) $\times$ c $0,02586=$ kolesterol (mmol/L)

Analisis Data Uji Efektivitas. Data tersebut dianalisis untuk diuji normalitasnya dengan KolmogorovSmirnov z test $(\mathrm{p}>0,05)$ dan Shapiro
Wilk ( $>0,05)$. Hasil uji normalitas ini untuk menentukan analisis berikutnya, yaitu parametrik bila data berdistribusi normal atau non parametrik bila data berdistribusi tidak normal. Tahap selanjutnya uji homogenitas dengan Levene test $(p>0,05)$ untuk mengetahui data homogen atau tidak homogen. Tahap selanjutnya uji parametrik menggunakan One way Anova dengan metode LSD untuk mengetahui perbedaan antar kelompok mikroemulsi bawang dayak, kelompok kontrol positif, dan kelompok kontrol negatif yang diberi perlakuan yang berbeda.

\section{HASIL DAN PEMBAHASAN}

Pembuatan esktrak etanol biji pala dilakukan dengan cara maserasi. Metode ini dipilih karena proses pengerjaanya yang mudah serta peralatan yang digunakan sederhana.

Uji efektifitas sediaan mikroemulsi ekstrak bawang dayak dan mikroemulsi daun bungur menggunakan 3 konsentrasi pengujian. Pengamatan dilakukan selama 20 hari.

Tabel 1. Hasil Pengukuran Kadar Kolesterol Total (mg/dl) serta Persen Kenaikan dan Persen Penurunan Semua Kelompok Perlakuan

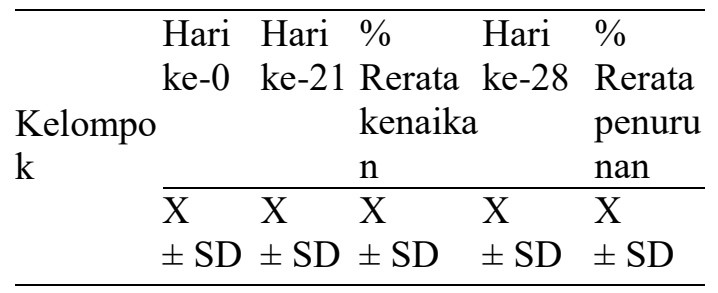




\begin{tabular}{|c|c|c|}
\hline $\begin{array}{lc}\text { Mikroem } 54,8 & 82,6 \\
\text { ulsi } \quad \pm 8,31 \pm \\
\text { bawang } & 11,78 \\
\text { dayak } & \\
180 \mathrm{mg} / 2 & \\
00 \mathrm{gBB} & \\
\end{array}$ & $\begin{array}{l}52,52 \quad 54,2 \\
\pm 22,94 \pm 9,23\end{array}$ & $\begin{array}{l}34,53 \\
\pm \\
2,57^{\mathrm{ab}}\end{array}$ \\
\hline 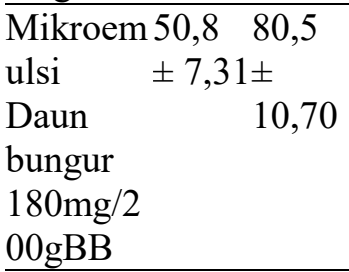 & $\begin{array}{ll}55,52 & 52,29 \pm \\
\pm 21,80 & 7,23\end{array}$ & $\begin{array}{l}=35,34 \\
\pm \\
3,24^{\mathrm{ab}}\end{array}$ \\
\hline 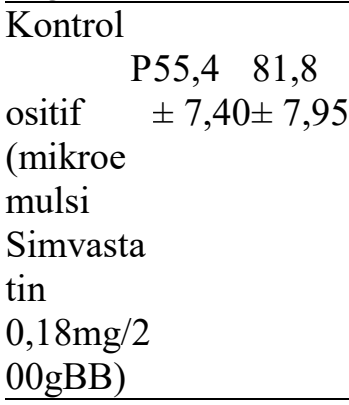 & $\begin{array}{cc}49,34 & 52,4 \\
5 \pm 21,00 \pm 3,05\end{array}$ & $\begin{array}{l}35,43 \\
\pm \\
7,52^{\mathrm{a}}\end{array}$ \\
\hline $\begin{array}{lcc}\text { Kontrol } & 52,6 & 79,6 \\
& \mathrm{n} \pm 7,47 \pm \\
\text { egatif } & 11,67 \\
\text { (Mikroe } & \\
\text { mulsi } & \\
\text { Placebo) } & \end{array}$ & $\begin{array}{lc}51,7 & 67 \\
\pm 11,27 \pm 9,6\end{array}$ & $\begin{array}{l}15,76 \\
\pm 3,45\end{array}$ \\
\hline
\end{tabular}

Mikroemulsi Bawang dayak mengandung berbagai bahan aktif, beberapa kandungan bahan aktif didalamnya diduga mampu menurunkan kadar kolesterol total dalam darah, seperti flavonoid dapat menurunkan kadar kolesterol darah pada hewan uji disebabkan karena flavonoid dapat mencegah enzim HMG-CoA reduktase sehingga sintesis kolesterol menurun sehingga mengakibatkan kadar kolesterol dalam darah menurun.

Flavonoid dapat bertindak sebagai kofaktor enzim kolesterol esterase dan inhibitor absorbsi kolesterol makanan dengan menghambat pembentukan misel sehingga penyerapan kolesterol dari makanan terhambat maka tidak terjadi peningkatkan kolesterol dalam darah hewan uji. Jenis flavonoid juga bersifat sebagai antioksidan dalam umbi bawang dayak adalah kuersetin. Kuersetin termasuk dalam kelompok flavonol. Antioksidan yang kuat dari kuersetin menimbulkan efek menguntungkan pada fungsi endotel yaitu menurunkan oksidasi LDL dan meningkatkan produksi nitric oxide (NO) selain itu kuersetin juga dapat menangkap radikal bebas. Oksidasi LDL akan menginduksi respon inflamasi pada endotel. Nitric oxide adalah vasodilator endogenous yang mempunyai kemampuan anti aterosklerosis. Oksidasi LDL akan menghasilkan Reactive Oxygen Species (ROS) yang bersifat toksik, dan jika berikatan dengan NO akan terbentuk peroksinitrit oksidan.

Oksidasi kolesterol ini akan memicu terjadinya proses aterosklerosis. Tanin yang terkandung dalam bawang dayak dapat bereaksi dengan enzim mukosa dan sel epitel usus. Enzim tersebut berikatan dengan tanin, mengakibatkan enzim mengendap di permukaan usus, sehingga penyerapan makanan yang mengandung lemak akan terhambat.

Saponin dapat membentuk ikatan kompleks dengan kolesterol dari makanan. Ikatan kompleks tersebut tidak dapat larut di dalam usus, sehingga kolesterol tersebut tidak dapat diserap, saponin dapat bergabung dengan asam empedu dan kolesterol dari makanan membentuk 
micelles yang juga tidak dapat diserap oleh usus, sehingga saponin dan kolesterol yang terikat dapat keluar dari saluran cerna. Hal ini dapat menyebabkan kolesterol dalam tubuh dapat berkurang.

KESIMPULAN

Ekstrak bawang dayak positif mengandung senyawa metabolit meliputi flavonoid, alkaloid, tanin, saponin, steroid, dan terpenoid. Pemberian mikroemulsi ekstrak bawang dayak (Eleutherine bulbosa Mill. Urb.) dan ekstrak mikroemulsi daun bungur (Eleutherine bulbosa Mill. Urb.) dapat menurunkan kadar koleseterol total pada tikus yang diinduksi pakan tinggi kolesterol.

\section{DAFTAR PUSTAKA}

Malik, M.A., Yanti, M.M., dan Stefani, H.M.K. 2013. Gambaran Kadar Kolesterol Total Darah pada Mahasiswa Angkatan 2011 Fakultas Kedokteran Universitas Sam Ratulangi dengan Indeks Massa Tubuh 18,5$22,9 \mathrm{Kg} / \mathrm{m}^{2}$. Journal e-Biomedik.1. (2) : pp. 1008-1013.

Adib, M. 2009. Kupas Tuntas Kolesterol. Yogyakarta : Dianloka Pustaka Populer.

Tatto, Dermiati., Dewi, N.P., Tibe, F. 2017. Efek Antihiperkolesterol dan Antihiperhgikemik Ekstrak Daun Ceremai (Phyllantus acidus (L.) Skeels) padaTikus Putih Jantan (Rattus norvegicus) Hiperkolesterol Diabetes. Jurnal Farmasi Galenika. Vol. 3 (2)
Hlm : 157 - 164. STIFAR Pelita Mas Palu.

Indraswari, Arista. 2008. Optimasi Pembuatan Ekstrak Daun Dewandaru (Eugenia uniflora L.) Menggunakan Metode Maserasi Dengan Parameter Kadar Total Senyawa Fenolik Dan Flavonoid. Fakultas Farmasi Muhammadiyah Surakarta. 